\title{
THE IMPROVEMENT OF PHOTOSTABILITY AND ANTIOXIDANT ACTIVITY OF trans-RESVERATROL BY CYCLODEXTRINS
}

Ivana Savić-Gajić1* ${ }^{*}$ Ivan M. Savić1, Vesna D. Nikolić ${ }^{1}$, Ljubiša B. Nikolić1, Mirjana M. Popsavin², Srđan J. Rakić3

\footnotetext{
${ }^{1}$ Faculty of Technology, University of Niš, Leskovac, Serbia,

2 Institute of Chemistry, Faculty of Sciences, University of Novi Sad, Novi Sad, Serbia,

${ }^{3}$ Department of Physics, Faculty of Sciences, University of Novi Sad, Novi Sad, Serbia.
}

The aim of this paper was to prepare the solid-state inclusion complexes of trans-resveratrol with $\beta$-cyclodextrin and (2-hydroxypropyl)- $\beta$-cyclodextrin from ethanol-water mediums in order to improve its physico-chemical properties. The structure characterization was performed using FTIR, XRD and NMR methods. It was confirmed that the complexed trans-resveratrol has higher photostability than free trans-resveratrol. The results of DPPH assay suggested that the complexes have enhanced the antioxidant activity compared with trans-resveratrol. The inclusion complex with (2-hydroxypropyl)- $\beta$-cyclodextrin showed a better antioxidant activity than the complex based on $\beta$-cyclodextrin. The prepared inclusion complexes represent potential pharmaceutical active substances for a new products design.
(ORIGINAL SCIENTIFIC PAPER) UDC 547.56:547.458.68:615

Keywords: trans-resveratrol, $\beta$-cyclodextrin, (2-hydroxypropyl)- $\beta$ cyclodextrin, antioxidant activity, photostability.

\section{Introduction}

Resveratrol (3,5,4'-trihydroxy-trans-stilbene) is a natural polyphenol compound which is composed of two aromatic rings bonded by an unsaturated alkene bridge (Figure 1). The presence of double bonds allows two geometrical isomers of resveratrol (cis- and trans-resveratrol). It can exist in the free form or in the form of glycoside.
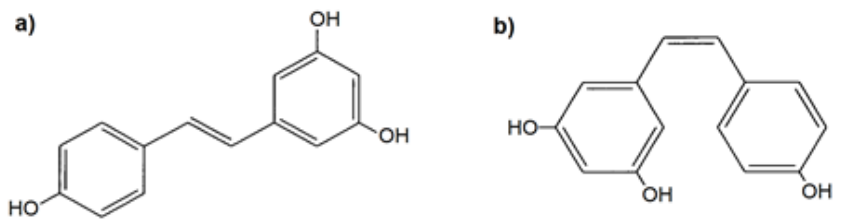

Figure 1. Structure of: a) trans- and cis-resveratrol.

Resveratrol is a very efficient antioxidant [1,2] and can be used in the prevention of cardiovascular disease and cancer. It helps to slow the aging process and protects the body's immune system. In addition, it has anti-inflammatory [3] and antimicrobial properties [4]. However, its use in pharmacy is limited due to their poor aqueous solubility (about $0.03 \mathrm{~g} \mathrm{dm}^{-3}$ at room temperature), low oral bioavailability and stability [5]. Although it is absorbed about $70 \%$ after oral administration, the bioavailability of resveratrol is very small (less than 1\%) due to its rapid metabolism and excretion. Numerous studies showed that resveratrol is an unstable substance either in the pure form or in the plant extracts [6-8]. Under the effect of light [9] and high $\mathrm{pH}$ value, trans-resveratrol is subjected to isomerization and transitions in the cis- form, which is less pharmacologically active [10]. Different approaches were applied in order to improve the drug stability, increase bioavailability and minimize side-effects of resveratrol. Due to low bioavailability and stability, the structure of resveratrol was modified to give a series of analogs thereof, which may be promising candidates for the future oncology treatment [11]. Today, more and more attention is paid to the development of novel drug delivery systems available to encapsulate, protect and release resveratrol [2, 12-16]. Cyclodextrins (CDs) and their derivatives are also used in the modification of resveratrol properties [17-21]. Apparent formation constants of resveratrol complexes with CDs were determinated using HPLC, enzymatic, solubility and fluorimetric assays [22-24]. In the literature, there are numerous reports on the antioxidant activity of resveratrol:CD inclusion complexes [25-28].

Until now, the preparation of resveratrol complexes with $\beta-C D$ and HP- $\beta-C D$ was commonly conducted by wet technologies, where usually highly amorphous products are got. Due to this way of preparation and loss of the inclusion complexes crystallinity, wrong conclusions can be derived during solid-state characterization. Therefore, Trollope et al. [19] prepared resveratrol inclusion complexes with methylated CDs (permethylated $\alpha-C D$, permethylated $\beta-C D$ and 2,6-dimethylated $\beta-C D$ ) in the crystalline form using various preparative methods such as physical mixing, kneading or co-crystallization from different solutions by co-evaporation or exposure to microwave radiation.

\footnotetext{
* Author address: Ivana M. Savić-Gajić, Faculty of Technology, University of Niš, Bulevar oslobodjenja 124, 16000 Leskovac, Serbia

E-mail:vana.savic@yahoo.com

The manuscript received: March,22, 2017.

Paper accepted: May,9, 2017.
} 
Due to the lack of information about the structure of solid-state inclusion complexes between resveratrol and $\beta-C D$ or HP- $\beta-C D$ in the literature, the aim of this study was to prepare the corresponding complexes. The inclusion complexes were prepared by co-evaporation. The structural characterization of the complexes was achieved using FTIR, XRD and NMR methods. The photostability and antioxidant activity of free and complexed trans-resveratrol were defined in order to analyze the advantages of inclusion into the cavity of $C D s$.

\section{Experimental}

\section{Reagents}

Trans-resveratrol $(>99,4 \%)$ was purchased from Dr. Ehrenstorfer $\mathrm{GmbH}$ (Augsburg, Germany). $\beta$-CD (purity $98 \%, \mathrm{Mr} \sim 1,135$ ), HP- $\beta-\mathrm{CD}$ (purity $97 \%, \mathrm{Mr} \sim 1,540$ ) and 2,2-diphenyl-1-picrylhydrazyl (DPPH) were supplied by Sigma Aldrich (Taufkirchen, Germany). Potassium bromiede was FTIR grade and obtained from Merck (Darmstadt, Germany). Ethanol (96\%, v/v) was purchased from Zorka Pharma (Šabac, Serbia), while butylated hydroxytoluene $(\mathrm{BHT})$ was supplied by Centrohem (Stara Pazova, Serbia). All other used reagents and solvents were analytical grade.

\section{Preparation of the inclusion complexes}

Inclusion complexes between trans-resveratrol and CDs were prepared in 1:1 molar ratio. Trans-resveratrol (30 mg) was mixed with $\beta-C D(149.18 \mathrm{mg})$ or HP- $\beta-C D$ $\left(202.42 \mathrm{mg}\right.$ ) and dissolved in the $35 \mathrm{~cm}^{3}$ mixture of distilled water and $96 \%(\mathrm{v} / \mathrm{v})$ ethanol. Water and $96 \%(\mathrm{v} / \mathrm{v})$ ethanol were mixed in 5:2 volume ratio, which represents the $23.3 \%(\mathrm{v} / \mathrm{v})$ ethanol solution. Thus prepared mixture was equilibrated using a magnetic stirrer (HAN$\mathrm{NA} \mathrm{HI300)}$ at the stirring speed of $600 \mathrm{rpm}$ and room temperature for $24 \mathrm{~h}$. The samples were protected from the effect of daylight using aluminium foil. The solutions of inclusion complexes were evaporated under vacuum at $60^{\circ} \mathrm{C}$ using a rotavapor.

\section{Structural characterization of the inclusion complexes}

Infrared spectroscopy with Fourier transformation (FTIR) Infrared spectra of trans-resveratrol, $\beta-C D, H P-\beta-C D$ and appropriate inclusion complexes were recorded by a technique of $\mathrm{KBr}$ transparent pellets. Firstly, $150 \mathrm{mg}$ of $\mathrm{KBr}$ and $1 \mathrm{mg}$ of the sample were ground in a mortar in order to homogenize the mixture, and then it was compressed at the pressure of $200 \mathrm{MPa}$ under vacuum. The spectra were measured in the wavelength range of $4000-400 \mathrm{~cm}^{-1}$ with the resolution of $4 \mathrm{~cm}^{-1}$ using FTIR spectrophotometer (Bomem Hartmann \& Braun MBseries) and processed using the software Win-Bomem Easy.

\section{X-ray Powder Diffraction (XRD)}

XRD spectra of the samples were recorded using
XRD diffractometer. The samples were irradiated by monochromatic $\mathrm{Cu}-\mathrm{ka}$ radiation and analyzed in the range of $2 \theta$ angle between 3 and $60^{\circ}$. The increment of $2 \theta$ angle was $0.05^{\circ}$ with recording time of $2 \mathrm{~s}$. The used voltage was $40 \mathrm{kV}$, while the current was $12 \mathrm{~mA}$, respectively.

\section{Nuclear Magnetic Resonance (NMR)}

$1 \mathrm{H}-\mathrm{NMR}$ spectra of the inclusion complexes of transresveratrol with CDs were recorded on a Bruker Avance III NMR spectrophotometer equipped with a glass cuvette of $5 \mathrm{~mm}$ diameter. The recording was performed by the pulse method with multiple pulse repetitions under the operating frequency of $250 \mathrm{MHz}$ at room temperature. The heavy water $\left(D_{2} O\right)$ was used as a solvent.

Analisys of trans-resveratrol by UV method

A series of solutions were prepared by dissolving the methanol solution of trans-resveratrol $\left(50 \mu \mathrm{g} \mathrm{cm}^{-3}\right)$ in the concentration range of $1-8 \mu \mathrm{g} \mathrm{cm}^{-3}$. The calibration curve was constructed by measuring the absorbance of the samples at $303 \mathrm{~nm}$ in quartz cuvettes $(1 \times 1 \times 4.5 \mathrm{~cm})$ on UV spectrophotometer (Varian Cary-100 Conc.). The equation of the calibration curve can be shown as follows $\mathrm{A}_{303}=0.092 \mathrm{C}\left(\mu \mathrm{g} \mathrm{cm}^{-3}\right)-0.0256\left(\mathrm{R}^{2}=0.9958\right)$. The proposed regression model was used to determine the content of trans-resveratrol during the photostability studies. The control solutions consisted of the equivalent amount of CDs. Absorbance of the samples was measured at room temperature. Methanol was used as a blank sample. The percentage of trans-resveratrol degradation was calculated in the following way (Equation 1):

$$
\text { degradation of trans - resveratrol }(\%)=\frac{C_{t}}{C_{0}} \times 100 \text {. }
$$

where are, $\mathrm{C}_{0}$ - the initial concentration of trans-resveratrol, $C_{t}-$ the concentration of trans-resveratrol after irradiation.

Photostability experiments of the inclusion complexes

In order to investigate the photostability of trans-resveratrol and inclusion complexes in methanol, the initial concentrations of the samples were prepared as equivalent to $8 \mu \mathrm{g} \mathrm{cm}^{-3}$ of trans-resveratrol. The samples were sonificated for $15 \mathrm{~min}$, and then exposed to UVA and UVB irradiation in different intervals (0-600 s). The radiation of the samples was performed in the photochemical reactor "Rayonet" with ten simetrically UVA or UVB lamps. The maximum emission of UVA and UVB lamps was at 350 and $300 \mathrm{~nm}$, respectively. During irradiation, the samples were kept in quartz cuvettes $(1 \times 1 \times 4.5 \mathrm{~cm})$ mounted on a circular rotating bracket. The total energy flux of UVA and UVB radiation was 11.5 and $14.5 \mathrm{~W} \mathrm{~m}^{-2}$, respectively. The irradiated samples were further analyzed using the UV spectrophtometry method.

Antioxidant activity

The antioxidant activity of trans-resveratrol and inclu- 
sion complexes was determined using DPPH assay and compared with the synthetic antioxidant $\mathrm{BHT}$. Exactly $1 \mathrm{~cm}^{3}$ of DPPH ethanol solution $\left(3 \times 10^{-4} \mathrm{~mol} \mathrm{dm}^{-3}\right)$ was added to $2.5 \mathrm{~cm}^{3}$ ethanol solution of trans-resveratrol (6.25-400 $\left.\mu \mathrm{g} \mathrm{cm}^{-3}\right)$ or BHT $\left(7.81-250 \mu \mathrm{g} \mathrm{cm}^{-3}\right)$ or inclusion complexes of trans-resveratrol: $\beta-C D\left(25-500 \mu \mathrm{g} \mathrm{cm}^{-3}\right)$ and trans-resveratrol:HP- $\beta-C D\left(25-300 \mu \mathrm{g} \mathrm{cm}^{-3}\right)$. The control solution was prepared by the dilution of $1 \mathrm{~cm}^{3}$ of DPPH solution with $2.5 \mathrm{~cm}^{3}$ ethanol. In order to perform the reactions, the samples were incubated for $30 \mathrm{~min}$. The absorbance of the samples was measured at $517 \mathrm{~nm}$ on UV spectrophotometer (Varian Cary-100 Conc.). The inhibition of DPPH radicals was calculated using the following Equation 2:

inhibition of DPPHradicals $(\%)=\frac{A_{c}-A_{s}}{A_{c}} \times 100$.

where are $A_{s}$ - absorbance of the samples treated with DPPH radicals, $A_{c}$ - absorbance of the control solution [29].

\section{Results and discussion}

\section{Structural characterization of inclusion complexes}

FTIR analysis

The strong band characteristic for trans-resveratrol can be noticed at $3290 \mathrm{~cm}^{-1}$, which originates from valence $\mathrm{v}(\mathrm{OH})$ vibrations of phenols (Figure 2a). The band at $3021 \mathrm{~cm}^{-1}$ is the result of the valence vibration of vinyl group vas $(=\mathrm{C}-\mathrm{H})$, while the bands at 2924 and $2852 \mathrm{~cm}^{-1}$ originate from the valence vibrations of $\mathrm{C}-\mathrm{H}$ bond from $\mathrm{CH}$ and $\mathrm{CH}_{2}$ groups. The valence vibrations $\mathrm{v}(\mathrm{C}=\mathrm{C})$ of the benzene ring were noticed at 1606, 1587, 1512 and $1444 \mathrm{~cm}^{-1}$. The in-plane deformational vibrations of $\mathrm{OH}$ group appeared at 1384 and $1325 \mathrm{~cm}^{-1}$, which is expected because they usually occur in the range of $1500-1300 \mathrm{~cm}^{-1}$. These bands are not of major importance for $\mathrm{OH}$ group identification. Additional bands of valence vibrations of $\mathrm{C}-\mathrm{C}$ bond at $1248 \mathrm{~cm}^{-1}$ and of $\mathrm{C}-\mathrm{O}$ bond from the phenol group at $1154 \mathrm{~cm}^{-1}$ were noticed in the spectrum. The deformational vibration of $\mathrm{C}-\mathrm{H}$ bond substituted on $\mathrm{C}=\mathrm{C}$ from trans orientation had a strong band at $966 \mathrm{~cm}^{-1}$. The band at $831 \mathrm{~cm}^{-1}$ originates from the deformational vibration of $\mathrm{C}-\mathrm{H}$ bond of the benzene ring. The out-of-plane deformational vibration $\mathrm{y}(\mathrm{OH})$ of $\mathrm{OH}$ group has the band at $675 \mathrm{~cm}^{-1}$.

Broad bands at $3395 \mathrm{~cm}^{-1}$ and $3411 \mathrm{~cm}^{-1}$ are the result of the valence vibration of $\mathrm{O}-\mathrm{H}$ bond in the FTIR spectrum of $\beta-C D$ (Figure $2 b$ ) and HP- $\beta-C D$ (Figure $3 b$ ), respectively. Valence vibrations of $\mathrm{C}-\mathrm{H}$ bond from $\mathrm{CH}$ and $\mathrm{CH}_{2}$ group have bands at $2926 \mathrm{~cm}^{-1}$ for $\beta-C D$, i.e. 2976 and $2927 \mathrm{~cm}^{-1}$ for HP- $\beta-C D$. Deformation vibrations of $\mathrm{O}-\mathrm{H}$ bond for both molecules occurred at $1635 \mathrm{~cm}^{-1}$. Characteristic bands at 1412 and $1334 \mathrm{~cm}^{-1}$ or 1414 and $1378 \mathrm{~cm}^{-1}$ correspond to the deformation vibrations of $\mathrm{C}-\mathrm{H}$ bond in the structures of $\beta-C D$ and HP- $\beta-C D$, respectively. The sharp band at $1156 \mathrm{~cm}^{-1}$ indicates the presence of the valence vibration of $\mathrm{C}-\mathrm{C}$ bond. The bands in the range of $1100-1030 \mathrm{~cm}^{-1}$ originate from the valence vibration of $\mathrm{C}-\mathrm{O}$ bond and $\mathrm{OH}$ groups of $\beta-\mathrm{CD}$ or $\mathrm{HP}-\beta-\mathrm{CD}$. In the range of $950-700 \mathrm{~cm}^{-1}$, deformational vibrations of $\mathrm{C}-\mathrm{H}$ bond are present.

Broad bands can be noticed at $3399 \mathrm{~cm}^{-1}$ and $3423 \mathrm{~cm}^{-1}$, respectively, as the result of valence vibrations of $\mathrm{O}-\mathrm{H}$ bonds in the FTIR spectra of trans-resveratrol: $\beta-C D$ complex (Figure 2c) and trans-resveratrol:HP- $\beta-C D$ complex (Figure $3 c$ ). These bands of inclusion complexes were significantly shifted to high values of the wavenumber in comparison with the same band of free trans-resveratrol. In the case of trans-resveratrol: $\beta-C D$ complex, the band was shifted for 109 units while in the case of transresveratrol:HP- $\beta-C D$ complex the band was shifted for 133 units. If these bands are compared in relation to the bands from the spectra of $\beta-C D$ and HP- $\beta-C D$, they are shifted for 4 and 12 units, respectively. The band of vas $(=\mathrm{C}-\mathrm{H})$ was shifted to the lower wavenumber for about 40 units compared with the same band in the spectrum of trans-resveratrol. The band of the valence vibration of $\mathrm{C}-\mathrm{H}$ bond occurred at $2928 \mathrm{~cm}^{-1}$ in the spectra of both inclusion complexes. It was shifted for 4 units to higher values of the wavenumber compared with the spectrum of trans-resveratrol. Unlike the FTIR spectrum of transresveratrol, the presence of deformational vibrations of $\mathrm{O}-\mathrm{H}$ bonds was noticed at 1636 or $1640 \mathrm{~cm}^{-1}$ in the spectra of inclusion complexes. This fact indicates that $\mathrm{O}-\mathrm{H}$ bonds of CDs are included in complexing of trans-resveratrol. The bands at 1606 and $1587 \mathrm{~cm}^{-1}$, originating from valence vibrations of $\mathrm{C}=\mathrm{C}$ bond from the benzene ring, were not identified in the spectra of complexes, while the band at $1512 \mathrm{~cm}^{-1}$ had a significantly low intensity. The band at $1444 \mathrm{~cm}^{-1}$ for both inclusion complexes was shifted to higher wavenumbers (1451 and $1459 \mathrm{~cm}^{-1}$ ). These changes in the spectra indicate that $\mathrm{C}=\mathrm{C}$ bond of the ring probably participated in the complex formation. The lower intensity of deformational vibrations in plane $\delta(\mathrm{OH})$ were confirmed at $1382 \mathrm{~cm}^{-1}$ for both complexes. In the spectrum of the complex, the presence of the valence vibration of C-C bond was noticed at $1269 \mathrm{~cm}^{-1}$. In addition to that, the valence vibrations of $\mathrm{C}-\mathrm{O}$ bond from the phenolic group at 1158 or $1156 \mathrm{~cm}^{-1}$ were also noticed. Sharp bands at 1082 and $1050 \mathrm{~cm}^{-1}$ or at 1083 and $1044 \mathrm{~cm}^{-1}$ correspond to the valence vibrations of ether bond $\mathrm{C}-\mathrm{O}$ and hydroxyl groups of $\beta-\mathrm{CD}$ or HP- $\beta$ $C D$, respectively.

Based on the aforementioned changes in the FTIR spectra, it can be assumed that the Van der Waals interactions between trans-resveratrol and CDs are formed, i.e. that the inclusion complexes are probably prepared. 

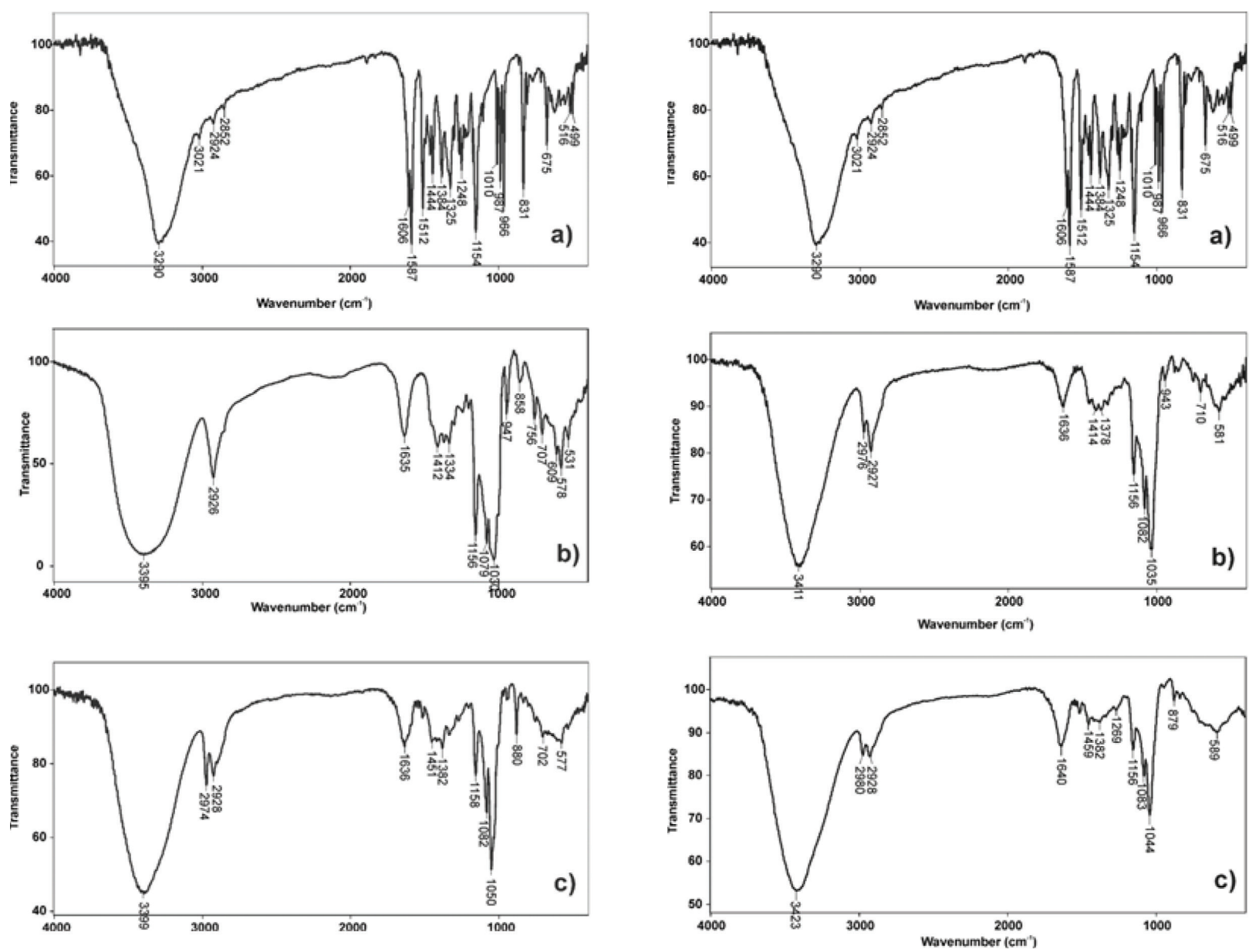

Figure 2. FTIR spectra: a) trans-resveratrol; b) $\beta-C D$; c) trans-resveratrol: $\beta-C D$ inclusion complex.

Figure 3. FTIR spectra: a) trans-resveratrol; b) HP- $\beta$ $C D$; $)$ trans-resveratrol:HP- $\beta-C D$ inclusion complex
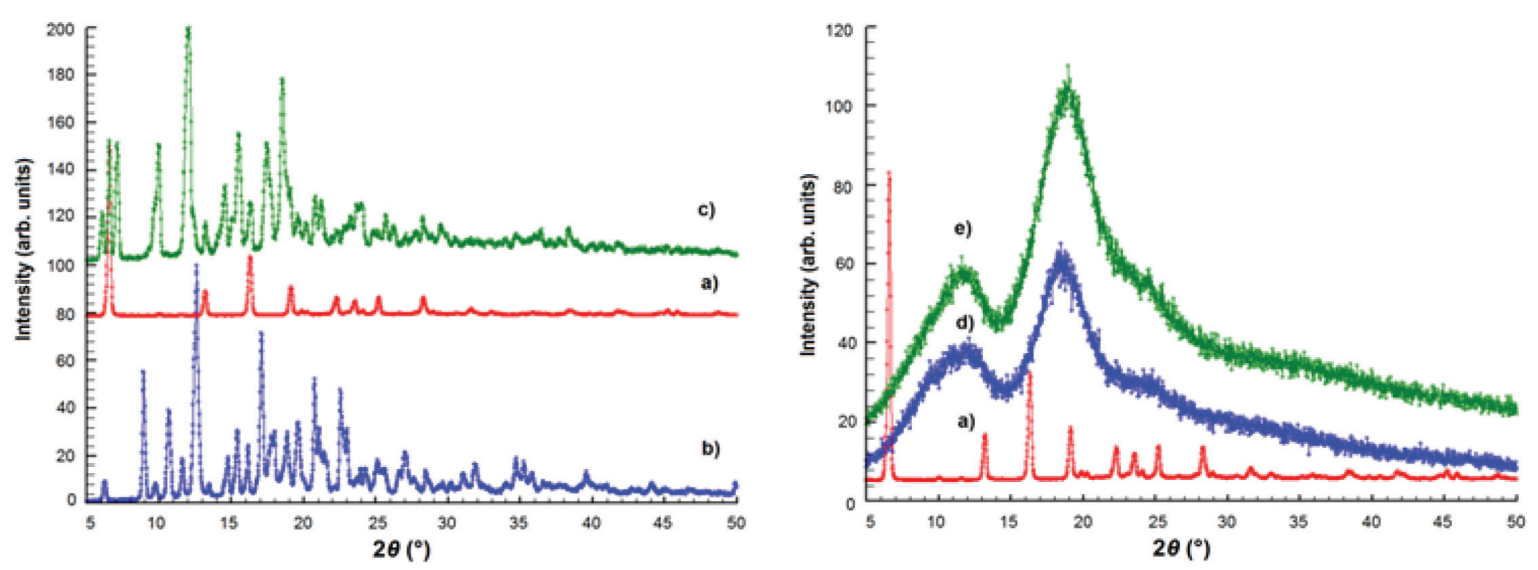

Figure 4. XRD diffractogram of: a) trans-resveratrol, b) $\beta-C D$ c) trans-resveratrol: $\beta-C D$ complex, $d) H P-\beta-C D$, e) trans-resveratrol:HP- $\beta-C D$ complex.

XRD analysis

$\mathrm{XRD}$ diffractograms of trans-resveratrol, complexing agents $(\beta-C D, H P-\beta-C D)$ and inclusion complexes are shown in Figure 4.

Trans-resveratrol diffractogram has the peaks at $7.1^{\circ}$; $13.3^{\circ} ; 16.5^{\circ} ; 19.2^{\circ}$ and $22.1^{\circ}$ which indicate its highly crystalline structure (Figure 4a). On the diffractogram of $\beta-C D$ (Figure $4 b$ ), the peaks that occured on $2 \theta$ of $6.2^{\circ}$, $8.9^{\circ}, 10.7^{\circ}, 11.8^{\circ}, 12.6^{\circ}, 15.5^{\circ}, 17.2^{\circ}, 19.6^{\circ}, 20.9^{\circ}$ and $22.8^{\circ}$ indicate that $\beta-C D$ has a typical crystal structure. In the diffractogram of trans-resveratrol: $\beta-C D$ complex (Figure $4 \mathrm{c}$ ), the change in the intensity and position of 
individual peaks can be noticed. The peaks of trans-resveratrol at $7.1^{\circ}$ and $19.2^{\circ}$ were shifted to $6.9^{\circ}$ and $18.6^{\circ}$, respectively, in the spectrum of the inclusion complex. In the diffractogram of the complex there is a certain change in comparison with the spectrum of $\beta-C D$. The peaks of $\beta-C D$ at $11.5^{\circ}, 17^{\circ}$ and $22.5^{\circ}$ are not present in the XRD spectrum of the complex with $\beta-C D$. The analysis of these diffraction patterns indicates that the inclusion complex was formed between trans-resveratrol and $\beta-C D$. A great number of clear defined peaks in the XRD spectrum of the complex with $\beta-C D$ also suggest that the newly created structure is of crystalline type. In the diffractogram of HP- $\beta-C D$ (Figure $4 d$ ), the absence of crystalline peaks indicate its amorphous structure. XRD spectrum of the trans-resveratrol:HP- $\beta-C D$ complex (Figure $4 \mathrm{e}$ ) has shown that the structure of this complex is also amorphous. Based on that, it can be concluded that there is the formation of the inclusion complex between trans-resveratrol and HP- $\beta-C D$.<smiles>Oc1ccc(C=Cc2cc(O)cc(O)c2)cc1</smiles>

a)

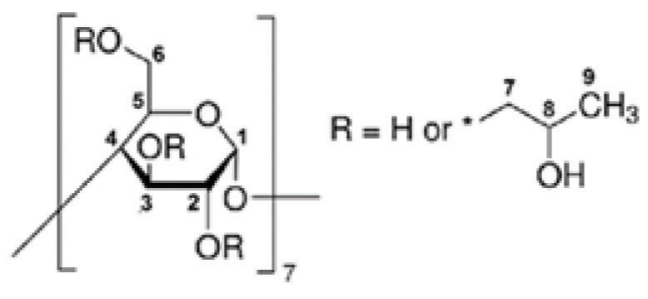

b)

Figure 5. Structure of trans-resveratrol (a), $\beta-C D$ and HP- $\beta-C D(b)$ with marked positions of atoms.

${ }^{1} \mathrm{H}-\mathrm{NMR}$ analysis

The structures of trans-resveratrol, $\beta-C D$ and HP- $\beta-$ CD with clearly marked positions of atoms are given in Figure 5.

Chemical shifts of signals in the ${ }^{1} \mathrm{H}-\mathrm{NMR}$ spectra of $\beta-C D$ and trans-resveratrol: $\beta-C D$ complex previously dissolved in $\mathrm{D} 2 \mathrm{O}$ at $25{ }^{\circ} \mathrm{C}$ are presented in Table 1. $\mathrm{H}-1$ proton has a chemical shift at $5.091 \mathrm{ppm}$ in the spectrum of $\beta-C D$, while chemical shifts of other protons are in the range of $\delta 3.5-4.0 \mathrm{ppm}$. Similar chemical shifts with some changes for given protons can be noticed in the spectrum of the inclusion complex. The greatest changes in chemical shifts $\Delta \delta+0.030,+0.035$ and +0.068 for $\mathrm{H}-6, \mathrm{H}-3$ and $\mathrm{H}-5$ protons, respectively, indicate that these protons participated in the intermolecular interaction with the molecule of trans-resveratrol. So, H-5 proton is mainly included in forming hydrogen bonds due to the highest change in chemical shifts.

Table 1. Chemical shifts $(\delta)$ of the signal in the ${ }^{1} \mathrm{H}-\mathrm{NMR}$ spectra of $\beta-C D$ and trans-resveratrol: $\beta-C D$ complex dissolved in $D_{2} \mathrm{O}$ at $25^{\circ} \mathrm{C}$

\begin{tabular}{llcc}
\hline & $\boldsymbol{\beta}-\mathrm{CD}$ & res: $\beta-C D$ complex & $\Delta \delta$ \\
\hline $\mathrm{H}-1$ & 5.091 & 5.100 & +0.009 \\
$\mathrm{H}-2$ & 3.650 & 3.660 & +0.010 \\
$\mathrm{H}-3$ & 3.956 & 3.991 & +0.035 \\
$\mathrm{H}-4$ & 3.610 & 3.612 & +0.002 \\
$\mathrm{H}-5$ & 3.814 & 3.882 & +0.068 \\
$\mathrm{H}-6$ & 3.870 & 3.900 & +0.030 \\
\hline \multicolumn{2}{l}{ res - resveratrol }
\end{tabular}

The chemical shifts which refer to HP- $\beta-C D$ and resveratrol:HP- $\beta-C D$ inclusion complex, as well as the change in the chemical shifts in the spectrum of HP- $\beta$ $C D$ after complexation are given in Table 2. The largest changes in the chemical shifts $\Delta \delta+0.033,+0.034$ and +0.068 were noticed for $\mathrm{H}-6, \mathrm{H}-3$ and $\mathrm{H}-5$ protons, respectively. The forming interactions between these protons are expected since they are located in the CD cavity. If the change in chemical shifts of CD after complexation is compared with trans-resveratrol, it can be observed that the change has almost the same order. In other words, the intermolecular interactions formed between the guest and host molecules are realized through the same protons.

Table 2. Chemical shifts $(\delta)$ of the signal in ${ }^{1} \mathrm{H}-\mathrm{NMR}$ spectra of HP- $\beta-C D$ and trans-resveratrol:HP- $\beta-C D$ complex dissolved in $\mathrm{D}_{2} \mathrm{O}$ at $25^{\circ} \mathrm{C}$

\begin{tabular}{|c|c|c|c|}
\hline & HP- $\beta-C D$ & res:HP- $\beta-C D$ complex & $\Delta \delta$ \\
\hline $\mathrm{H}-1$ & 5.227 & 5.250 & +0.023 \\
\hline $\mathrm{H}-1^{\prime}$ & 5.091 & 5.102 & +0.011 \\
\hline $\mathrm{H}-2$ & 3.659 & 3.670 & +0.011 \\
\hline $\mathrm{H}-3$ & 3.943 & 3977 & +0.034 \\
\hline $\mathrm{H}-4$ & 3.614 & 3.615 & +0.001 \\
\hline $\mathrm{H}-5$ & 3.807 & 3.875 & +0.068 \\
\hline $\mathrm{H}-6$ & 3.864 & 3.897 & +0.033 \\
\hline $\mathrm{CH}_{3}$ hydroxypropyl & 1.159 & 1.182 & +0.023 \\
\hline
\end{tabular}



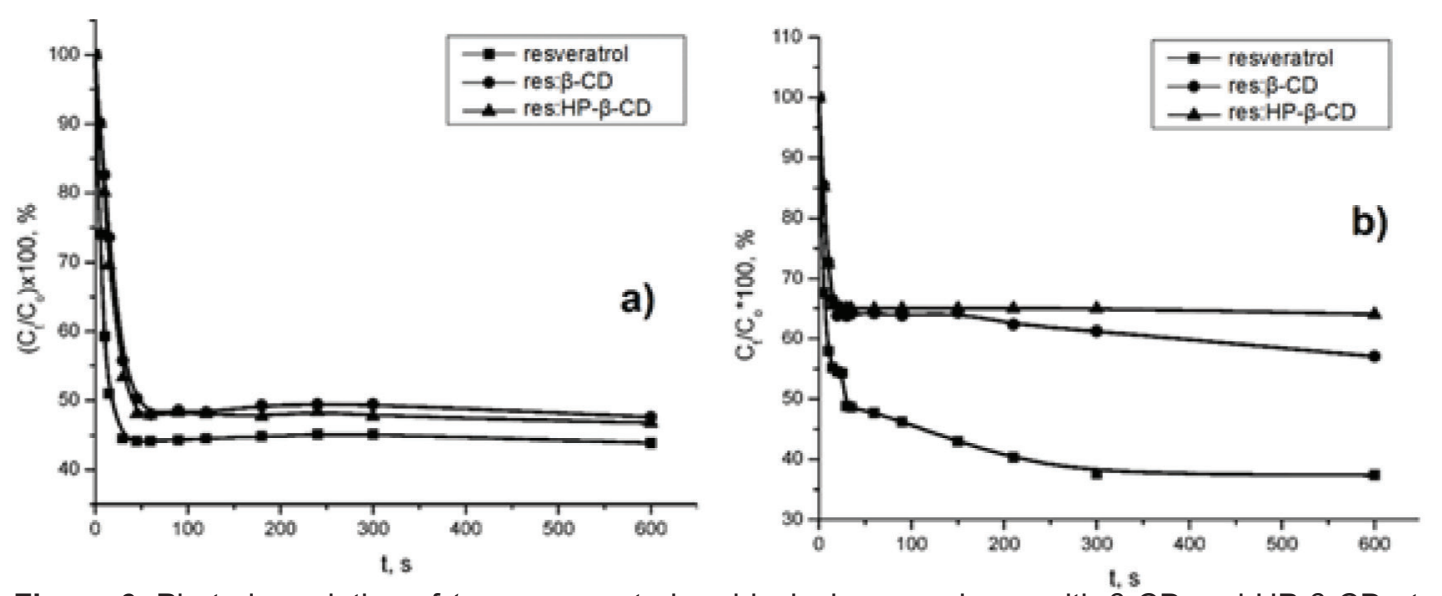

Figure 6. Photodegradation of trans-resveratrol and inclusion complexes with $\beta-C D$ and HP- $\beta-C D$ at: a) 350 b) $300 \mathrm{~nm}$.

Photostability of the inclusion complexes

In order to examine photostability, methanol solutions of complexes and trans-resveratrol were exposed to irradiation at 350 and $300 \mathrm{~nm}$ in the photochemical reactor. The stability of these complexes and trans-resveratrol in methanol was compared at the concentration of $8 \mathrm{mg} \mathrm{cm}^{-3}$. The concentration of trans-resveratrol in the pure and complexed form was monitored by UV method. The influence of complexing agents $\beta-C D$ and HP- $\beta-C D$ on photostability of trans-resveratrol is shown in Figure 6.

Based on the photodegradation profile of trans-resveratrol and its complexes, it can be concluded that CDs have a significant impact on the level of trans-resveratrol degradation. After UVA irradiation (350 nm) of the samples during $600 \mathrm{~s}$, the content of trans-resveratrol was decreased for $56.11 \%$, while its content in the complexes of trans-resveratrol: $\beta-C D$ and trans-resveratrol:HP- $\beta-C D$ was decreased for $52.4 \%$ and $53.24 \%$, respectively. For UVB radiation ( $300 \mathrm{~nm}$ ), the content of trans-resveratrol was decreased for $62.62 \%$. In the complexes of transresveratrol: $\beta-C D$ and trans-resveratrol:HP- $\beta-C D$, the content of trans-resveratrol was decreased for $42.95 \%$ and $35.92 \%$, respectively. The analysis of the obtained results indicates that the content reduction of trans-resveratrol in the pure and complexed form is less when exposed to UVA radiation for the same period, in comparison with UVB radiation. These results are expected, considering that UVA radiation has lower intensity compared to UVB. Also, in both types of radiation it was noted that the incorporation of trans-resveratrol in the CDs cavity leads to the reduction of its photodegradation.

Determination of the antioxidant activity of inclusion complexes

Due to the presence of two phenolic rings resveratrol can donate hydrogen atoms which are directly responsible for its antioxidant activity [30]. In the reaction with DPPH radicals, the donation of protons is possible over monophenolic hydroxyl groups. The antioxidant activity of trans-resveratrol, trans-resveratrol: $\beta-C D$ and trans-
resveratrol:HP- $\beta-C D$ inclusion complexes, as well as $\mathrm{BHT}$ is shown in Figure 7.

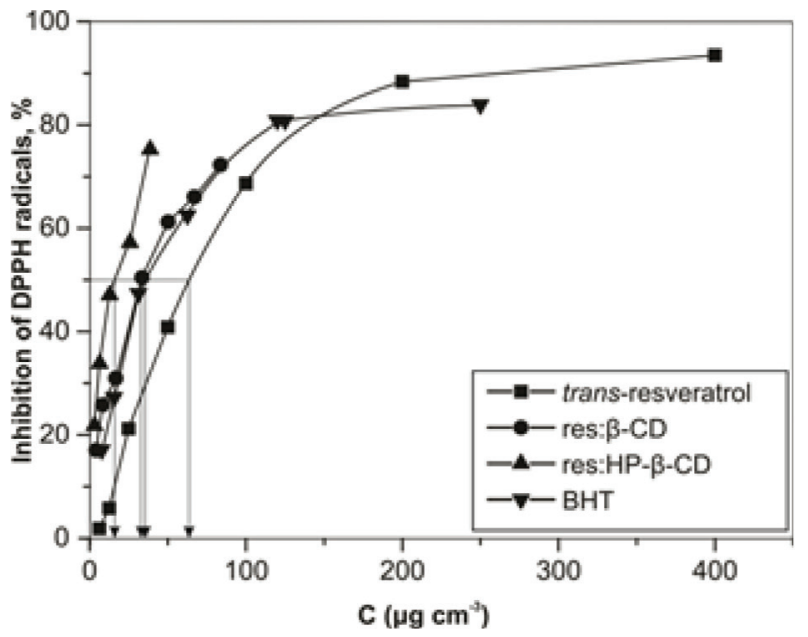

Figure 7. Antioxidant activity of BHT $\left(7.81-250 \mu \mathrm{g} \mathrm{cm}^{-3}\right)$, trans-resveratrol $\left(6.25-400 \mu \mathrm{g} \mathrm{cm}^{-3}\right)$, trans-resveratrol: $\beta-C D$ (equivalent to $4.2-83.7 \mu \mathrm{g} \mathrm{cm}^{-3}$ trans-resveratrol) and transresveratrol:HP- $\beta-C D$ (equivalent to $3.2-38.7 \mu \mathrm{g} \mathrm{cm}^{-3}$ trans-resveratrol) inclusion complexes.

After the complexation of trans-resveratrol with $\beta-C D$ and HP- $\beta-C D$, its ability to "scavange" DPPH radicals was significantly increased. The interaction of transresveratrol and CDs leads to the formation of hydrogen bonds between hydroxyl groups of trans-resveratrol and electronegative CDs atoms. The calculated $\mathrm{IC}_{50}$ value of trans-resveratrol was $66 \mu \mathrm{g} \mathrm{cm}^{-3}$, while the $\mathrm{IC}_{50}$ values of trans-resveratrol: $\beta-C D$ and trans-resveratrol:HP$\beta-C D$ inclusion complexes were found to be 197.6 and $129 \mu \mathrm{g} \mathrm{cm}^{-3}$, respectively. The concentration of $197.6 \mu \mathrm{g}$ $\mathrm{cm}^{-3}$ for trans-resveratrol: $\beta-C D$ complex was equivalent to $33.1 \mu \mathrm{g} \mathrm{cm}^{-3}$ of trans-resveratrol, and the concentration of $129 \mathrm{\mu g} \mathrm{cm}^{-3}$ for trans-resveratrol:HP- $\beta-C D$ complex was equivalent to $16.7 \mathrm{\mu g} \mathrm{cm}^{-3}$ of trans-resveratrol. BHT showed a slightly higher antioxidant activity compared with trans-resveratrol, because its $\mathrm{IC}_{50}$ value was 
$36.6 \mu \mathrm{g} \mathrm{cm}^{-3}$. Having in mind that $\mathrm{IC}_{50}$ value of transresveratrol:HP- $\beta-C D$ complex is almost two times lower than the value obtained for the trans-resveratrol: $\beta-C D$ complex, it can be concluded that trans-resveratrol:HP$\beta-C D$ complex showed a better antioxidant activity.

\section{Conclusion}

The results of FT-IR, NMR and XRD analyses have shown that the complexation between trans-resveratrol and $\beta-C D$, i.e. HP- $\beta-C D$ was successfully achieved in $5: 2(\mathrm{v} / \mathrm{v})$ ethanol-water mediums at room temperature for $24 \mathrm{~h}$. Based on the photostability studies of complexed and noncomplexed trans-resveratrol in methanol, it was confirmed that CDs have a big influence on the transresveratrol degradation. Also, it was concluded that prepared inclusion complexes are more stable under UVA irradiation compared with UVB light. The antioxidative activity of trans-resveratrol in the pure and complexed form was analyzed by using DPPH assay. The transresveratrol-HP- $\beta-C D$ complex showed a better antioxidative activity compared with the standard of trans-resveratrol, as well as the trans-resveratrol: $\beta-C D$ complex. The prepared trans-resveratrol complexes with improved photostability and antioxidative activity can be found on the list of potential therapeutic agents for the production of new dermal and oral formulations for the treatment of human diseases.

\section{Acknowledgments}

This work was supported by the Ministry of Education, Science and Technological Development of the Republic of Serbia under the project TR-34012.

\section{References}

[1] R. Pangeni, J. K. Sahni, J. Ali, S. Sharma, S. Baboota, Resveratrol: review on therapeutic potential and recent advances in drug delivery, Expert Opinion on Drug Delivery, 11(8) (2014) 1285-1298.

[2] P. Benjasirimongkol, P. Sriamornsak, Stability study of resveratrol-loaded emulsions using pectin as an emulsifier, Asian Journal of Pharmaceutical Sciences, 11(1) (2016) 199-200.

[3] S. Bo, G. Ciccone, A. Castiglione, R. Gambino, F. De Michieli, P. Villois, M. Cassader, Anti-inflammatory and antioxidant effects of resveratrol in healthy smokers a randomized, double-blind, placebo-controlled, cross-over trial, Current Medicinal Chemistry, 20(10) (2013) 13231331.

[4] L. Paulo, M. Oleastro, E. Gallardo, J. A. Queiroz, F. Domingues, Anti-Helicobacter pylori and urease inhibitory activities of resveratrol and red wine, Food Research International, 44(4) (2011) 964-969.

[5] A. Amri, J. C. Chaumeil, S. Sfar, C. Charrueau, Administration of resveratrol: what formulation solutions to bioavailability limitations?, Journal of Controlled Release, 158(2) (2012) 182-193.

[6] A. Francioso, P. Mastromarino, A. Masci, M. d'Erme,
L. Mosca, Chemistry, stability and bioavailability of resveratrol, Medicinal Chemistry, 10(3) (2014) 237-245.

[7] J. Prokop, P. Abrman, A. L. Seligson, M. Sovak, Resveratrol and its glycon piceid are stable polyphenols, Journal of Medicinal Food, 9(1) (2006) 11-14.

[8] A. A. Bertelli, A. Gozzini, R. Stradi, S. Stella, A. Bertelli, Stability of resveratrol over time and in the various stages of grape transformation, Drug Experimental Clinical Research, 24(4) (1997) 207-211.

[9] Ž. Cvetković, V. D. Nikolić, I. M. Savić-Gajić, I. M. Savić, L. B. Nikolić, The investigation of thermal and photo stability of trans-resveratrol, Advanced Technology, 3(2) (2014) 25-34. (in Serbian)

[10] Š. Zupančič, Z. Lavrič, J. Kristl, Stability and solubility of trans-resveratrol are strongly influenced by $\mathrm{pH}$ and temperature, European Journal of Pharmaceutics and Biopharmaceutics, 93 (2015) 196-204.

[11] Q. Sun, J. Heilmann, B. König, Natural phenolic metabolites with anti-angiogenic properties-a review from the chemical point of view, The Beilstein Journal of Organic Chemistry,11(1) (2015) 249-264.

[12] G. Davidov-Pardo, D. J. McClements, Resveratrol encapsulation: designing delivery systems to overcome solubility, stability and bioavailability issues, Trends in Food Science \& Technology, 38(2) (2014) 88-103.

[13] Y. O. Jeon, J. S. Lee, H. G. Lee, Improving solubility, stability, and cellular uptake of resveratrol by nanoencapsulation with chitosan and y-poly (glutamic acid), Colloids and Surfaces. B: Biointerfaces, 147 (2016) 224-233.

[14] C. Hu, Q. Wang, C. Ma, Q. Xia, Non-aqueous self-doubleemulsifying drug delivery system: A new approach to enhance resveratrol solubility for effective transdermal delivery, Colloids and Surfaces. A: Physicochemical and Engineering Aspects, 489 (2016) 360-369.

[15] K. Bolko, A. Zvonar, M. Gašperlin, Mixed lipid phase SMEDDS as an innovative approach to enhance resveratrol solubility, Drug Development and Industrial Pharmacy, 40(1) (2014) 102-109.

[16] B. Balanč, K. Trifković, V. Đorđević, S. Marković, R. Pjanović, V. Nedović, B. Bugarski, Novel resveratrol delivery systems based on alginate-sucrose and alginatechitosan microbeads containing liposomes, Food Hydrocolloids, 61 (2016) 832-842.

[17] A. Duarte, A. Martinho, Â. Luís, A. Figueiras, M. Oleastro, F. C. Domingues, F. Silva, Resveratrol encapsulation with methyl- $\beta$-cyclodextrin for antibacterial and antioxidant delivery applications, LWT-Food Science and Technology, 63(2) (2015) 1254-1260.

[18] F. Silva, A. Figueiras, E. Gallardo, C. Nerín, F. C. Domingues, Strategies to improve the solubility and stability of stilbene antioxidants: a comparative study between cyclodextrins and bile acids, Food Chemistry, 145 (2014) 115-125.

[19] L. Trollope, D. L. Cruickshank, T. Noonan, S. A. Bourne, M. Sorrenti, L. Catenacci, M. R. Caira, Inclusion of transresveratrol in methylated cyclodextrins: synthesis and solid-state structures, The Beilstein Journal of Organic Chemistry, 10(1) (2014) 3136-3151.

[20] Z. Lu, R. Chen, H. Liu, Y. Hu, B. Cheng, G. Zou, Study of the complexation of resveratrol with cyclodextrins by spectroscopy and molecular modeling, Journal of Inclusion Phenomena and Macrocyclic Chemistry, 63(34) (2009) 295-300.

[21] C. Lucas-Abellán, I. Fortea, J. M. López-Nicolás, E. 
Núñez-Delicado, Cyclodextrins as resveratrol carrier system, Food Chemistry, 104(1) (2007) 39-44.

[22] J. M. López-Nicolás, E. Núñez-Delicado, A. J. PérezLópez, Á. C. Barrachina, P. Cuadra-Crespo, Determination of stoichiometric coefficients and apparent formation constants for $\beta$-cyclodextrin complexes of transresveratrol using reversed-phase liquid chromatography, Journal of Chromatography A, 1135(2) (2006) 158-165.

[23] J. M. López-Nicolás, F. García-Carmona, Rapid, simple and sensitive determination of the apparent formation constants of trans-resveratrol complexes with natural cyclodextrins in aqueous medium using HPLC, Food Chemistry, 109(4) (2008) 868-875.

[24] C. Lucas-Abellán, M. I. Fortea, J. A. Gabaldón, E. NúñezDelicado, Complexation of resveratrol by native and modified cyclodextrins: determination of complexation constant by enzymatic, solubility and fluorimetric assays, Food Chemistry, 111(1) (2008) 262-267.

[25] Z. Lu, B. Cheng, Y. Hu, Y. Zhang, G. Zou, Complexation of resveratrol with cyclodextrins: solubility and antioxidant activity, Food Chemistry, 113(1) (2009) 17-20.

[26] C. Lucas-Abellán, M. T. Mercader-Ros, M. P. Zafrilla, J. A. Gabaldón, E. Núñez-Delicado, Comparative study of different methods to measure antioxidant activity of resveratrol in the presence of cyclodextrins, Food and Chemical Toxicology, 49(6) (2011) 1255-1260.

[27] C. Lucas-Abellán, M. T. Mercader-Ros, M. P. Zafrilla, M. I. Fortea, J. A. Gabaldón, E. Núñez-Delicado, ORACfluorescein assay to determine the oxygen radical absorbance capacity of resveratrol complexed in cyclodextrins, Journal of Agricultural and Food Chemistry, 56(6) (2008) 2254-2259.

[28] L. Lu, S. Zhu, H. Zhang, F. Li, S. Zhang, Theoretical study of complexation of resveratrol with cyclodextrins and cucurbiturils: structure and antioxidative activity, RSC Advances, 5(19) (2015) 14114-14122.

[29] Ž. S. Cvetković, V. D. Nikolić, I. M. Savić, I. M. Savić-Gajić, L. B. Nikolić, Development and validation of an RP-HPLC method for quantification of trans-resveratrol in the plant extracts, Hemijska Industrija, 69(6) (2015) 679-687.

[30] I. Gülçin, Antioxidant properties of resveratrol: a structureactivity insight, Innovative Food Science and Emerging Technologies, 11 (2010) 210-218.

\section{Izvod \\ POBOLJŠANJE FOTOSTABILNOSTI I ANTIOKSIDATIVNE AKTIVNOSTI trans-RESVERATROLA PRIMENOM CIKLODEKSTRINA}

Ivana Savić-Gajić ${ }^{1}$, Ivan M. Savić ${ }^{1}$, Vesna D. Nikolić ${ }^{1}$, Ljubiša B. Nikolić1, Mirjana M. Popsavin², Srđan J. Rakić3

\footnotetext{
${ }^{1}$ Tehnološki fakultet, Univerzitet u Nišu, Leskovac, Srbija,

2Departman za hemiju, Prirodno-matematički fakultet, Univerzitet u Novom Sadu, Novi Sad, Srbija,

${ }^{3}$ Departman za fiziku, Prirodno-matematički fakultet, Univerzitet u Novom Sadu, Novi Sad, Srbija.
}

Cilj ovog rada bio je priprema inkluzionih kompleksa trans-resveratrola sa $\beta$-ciklodekstrinom i (2-hidroksipropil)- $\beta$-ciklodekstrinom u čvrstom stanju iz vodenoetanolnog medijuma radi poboljšanja njegovih fizičko-hemijskih svojstava. Strukturna karakterizacija pripremljenih kompleksa izvršena je primenom FTIC, XRD i NMR metoda. Utvrđeno je da kompleksirani oblik trans-resveratrola ima veću fotostabilnost od slobodnog trans-resveratrola. Rezultati DPPH testa pokazali su da kompleksi imaju poboljšanu antioksidativnu aktivnost u odnosu na transresveratrol. Inkluzioni kompleks sa (2-hidroksipropil)- $\beta$-ciklodekstrinom pokazuje bolju antioksidativnu aktivnost od kompleksa na bazi $\beta$-ciklodekstrina. Pripremljeni inkluzioni kompleksi predstavljaju potencijalne farmaceutske aktivne supstance za dizajniranje novih proizvoda.
(ORIGINALNI NAUČNI RAD) UDK 547.56:547.458.68:615

Ključne reči: trans-resveratrol, $\beta$-ciklodekstrin, (2-hidroksipropil)- $\beta$ ciklodekstrin, antioksidativna aktivnost, fotostabilnost. 